Mycologia, 96(5), 2004, pp. 1163-1170.

(C) 2004 by The Mycological Society of America, Lawrence, KS 66044-8897

\title{
Aquatic fungi from peat swamp palms: Phruensis brunneispora gen. et sp. nov. and its hyphomycete anamorph
}

Umpava Pinruan ${ }^{1}$

Department of Biology, Faculty of Science, Chiang Mai University, Chiang Mai, Thailand, 50200

Jariya Sakayaroj

E.B. Gareth Jones

National Centre for Genetic Engineering and Biotechnology, BIOTEC Central Research Unit, 113 Phahonyothin Road, Klong 1, Klong Luang, Pathumthani, Thailand, 12120

Kevin D. Hyde

Centre for Research in Fungal Diversity, Department of Ecology and Biodiversity, The University of Hong Kong, Pokfulam Road, Hong Kong SAR, Peoples' Republic of China

Abstract: Phruensis brunneispora is a new genus and species occurring on decaying trunks of the palm Licuala longecalycata in Sirindhorn Peat Swamp Forest, Thailand. We compare the genus with other aquatic ascomycetes with falcate septate ascospores: Pseudohalonectria and Ophioceras. Ascospores differ from species in these genera in being brown with lighter end cells. Also, the ascus pore is subapical, with a channel leading to the apex. Lollipopaia minuta differs from Phruensis brunneispora in that the ascomata are borne in a stroma, asci have an apical pore and the ascospores are hyaline. No genus was found to accommodate the new species. Molecular analysis of rDNA ribosomal 18S confirmed the exclusion of the new species from Pseudohalonectria, and Ophioceras and Lollipopaia minuta formed a sister group with it. Phruensis brunneispora and Lollipopaia minuta grouped in the Diaporthales with $100 \%$ bootstrap support. Therefore, both morphological and molecular evidence supports erecting a new genus to accommodate this taxon. A hyaline Phialophora-like anamorph was formed when single ascospores were plated out on agar. The taxon is described and illustrated with light micrographs.

Key words: freshwater ascomycete, palm, peat swamp, taxonomy

\footnotetext{
Accepted for publication March 17, 2004.

${ }^{1}$ Corresponding author. E-mail: umpava328@biotec.or.th
}

\section{INTRODUCTION}

While investigating decaying palm material in Sirindhorn Peat Swamp Forest, Thailand (Hyde et al 2002, McKenzie et al 2002, Pinruan et al 2002), we collected a Pseudohalonectria-like ascomycete with brown versicolorous ascospores and isolated it into axenic culture. The isolate resembles species in the genera Pseudohalonectria, Ophioceras (Sordariales incertae sedis) and Lollipopaia (Diaporthales). Pseudohalonectria was described from balsawood submerged in a freshwater lake in Japan (Minoura and Muroi 1978) with $P$. lignicola as the type species. Eight additional species subsequently have been described (Shearer 1989, Hyde et al 1999, Cai et al 2002). Pseudohalonectria is characterized by bright yellow to brown ascomata with erumpent, cylindrical, periphysate necks and a 3-layered peridium; asci are unitunicate, cylindrical to clavate, with a nonamyloid, thimble-shaped, refractive apical apparatus, and ascospores are cylindrical, smooth, hyaline to slightly colored and usually multiseptate (Shearer 1989). Ophioceras is similar to Pseudohalonectria, and both are referred to Sordariales incertae sedis based on phylogenetic analysis of rDNA restriction and sequence data (Chen et al 1995). These molecular data confirmed that the two genera are distinct and well supported by $80-86 \%$ bootstrap values.

The new ascomycete differs from Pseudohalonectria in that it lacks the characteristic yellow pigmentation of the ascomata in nature and in culture the peridium is 2-layered, the ascospores are versicolored and produce an anamorph with hyaline falcate phialidic conidia. Lollipopaia minuta shows similarities to the new taxon, especially in the falcate, septate ascospores. Phruensis brunneispora differs in that L. minuta has a weakly developed stroma, the ascus pore is apical, the ascospores are hyaline and no anamorph has been reported. In this study we use phylogenetic analyses to investigate whether this palm ascomycete is congeneric with Pseudohalonectria, Ophioceras or Lollipopaia, genera from freshwater habitats with similar septate cylindrical ascospores.

\section{MATERIALS AND METHODS}

Collection and isolation.-During May 2001, submerged palm material was collected from Sirindhorn Peat Swamp 
TABLE I. Sequences from this study and those obtained from GenBank

\begin{tabular}{|c|c|c|}
\hline Classification & Taxon & $\begin{array}{c}\text { GenBank } \\
\text { accession } \\
\text { numbers }\end{array}$ \\
\hline \multirow[t]{11}{*}{ Order Diaporthales } & Apioplagiostoma aceriferum (Cooke) M.E. Barr & AF277111 \\
\hline & Apiosporopsis carpinea (Fr.) Traverso & AF277110 \\
\hline & Cryphonectria cubensis (Bruner) Hodges & L42439 \\
\hline & Cryphonectria parasitica (Murrill) M.E. Barr & U78541 \\
\hline & Endothia gyrosa (Schwein.) Fr. & $\mathrm{U} 78540$ \\
\hline & Gnomonia padicola (Lib.) Kleb. & AF277112 \\
\hline & Leucostoma persoonii (Nitschke) Höhn. & M83259 \\
\hline & Lollipopaia minuta Inderbitzin & AF301534 \\
\hline & Phruensis brunneispora strain 1 (BCC11169) & AY580160 \\
\hline & Phruensis brunneispora strain 2 (BCC14138) & AY581944 \\
\hline & Valsa ambiens Nitschke & AF277120 \\
\hline \multirow[t]{3}{*}{ Order Sordariales Incertae Sedis } & Ophioceras tenuisporum Shearer, J.L. Crane \& W. Chen, CS 652-1 & AF050475 \\
\hline & Pseudohalonectria falcata Shearer, CS 617-2C & AF050477 \\
\hline & Pseudohalonectria lignicola Minoura \& T. Muroi, J13-21 & AF050478 \\
\hline \multirow[t]{2}{*}{ Order Ophiostomatales } & Ophiostoma pilliferum (Fr.) Syd. \& P. Syd., CBS 129.32 & AJ243295 \\
\hline & Ophiostoma ulmi (Buisman) Nannf. & M83261 \\
\hline \multirow[t]{3}{*}{ Order Halosphaeriales } & Halosphaeria appendiculata Linder & $\mathrm{U} 46872$ \\
\hline & Nais inornata Kohlm. & AF050482 \\
\hline & Nimbospora effusa Jørg. Koch & $\mathrm{U} 46877$ \\
\hline \multirow[t]{2}{*}{ Order Microascales } & Microascus cirrosus Curzi & M89994 \\
\hline & Petriella setigera (Alf. Schmidt) Curzi & U43908 \\
\hline \multirow[t]{3}{*}{ Order Hypocreales } & Hypocrella sp. GJS 89-104 & U32409 \\
\hline & Hypomyces polyporinus Peck & U32410 \\
\hline & Nectria haematococca Berk. \& Broome & U32413 \\
\hline \multirow[t]{2}{*}{ Order Phyllachorales } & Collectotrichum gloeosporioides (Penz.) Penz. \& Sacc. & U76339 \\
\hline & Glomerella septospora Sivan. \& W.H. Hsieh & U78779 \\
\hline \multirow[t]{2}{*}{ Order Sordariales } & Chaetomium globosum Kunze & U20379 \\
\hline & Sordaria fimicola (Roberge ex Desm.) Ces. \& De Not. & X69851 \\
\hline \multirow[t]{2}{*}{ Order Xylariales } & Xylaria carpophila (Pers.) Fr. & $\mathrm{Z} 49785$ \\
\hline & Xylaria sp. PF 1022 & AB014042 \\
\hline \multirow[t]{2}{*}{ Order Pezizales } & Helvella terrestris (Velen.) Landvik & AF046216 \\
\hline & Morchella esculenta (L.) Pers. & $\mathrm{U} 42642$ \\
\hline
\end{tabular}

Forest, Narathiwat, Thailand. The material was returned to the laboratory, incubated in plastic boxes on damp tissue paper and examined within $4 \mathrm{wk}$. Single spore isolations were made on cornmeal agar (CMA), with added antibiotics to suppress bacterial growth, following the method of Choi et al (1999). Two strains of the fungus from different collections (Wah 113.1, Wah 113.2) were used for the molecular study. All observations, including photographic documentation and measurements of the fungus growing on wood, were of material mounted in water and examined with a differential interference microscope. Other collections subsequently have been made and treated in the same manner.

Growth of fungi, DNA extraction, amplification and sequencing.-Stock cultures of the fungus were maintained on CMA at 25 C. The fungus was grown in liquid GYP (glucose, yeast extract, peptone; Abdel-Wahab et al 2001) broth on a rotary shaker at $200 \mathrm{rpm}$ at $25 \mathrm{C}$. Fungal biomass was harvested by vacuum filtration and washed with sterile distilled water. The biomass was frozen in liquid nitrogen and ground with a mortar and pestle. DNA was extracted using a NucleoSpin ${ }^{\circledR}$ Plant DNA extraction kit (MACHEREY-NAGEL, Catalogue No. 740 590. 50). The small subunit ribosomal DNA (rDNA) was amplified using FINNZYMES, DyNAzyme $^{\text {II }}$ II DNA Polymerase Kit (MACHEREY-NAGEL, product code F-551S), in a Perkin Elmer thermal cycler. Primers NS1, NS4, NS5 and NS6 were used to amplify the small subunit rRNA (White et al 1990). The amplification cycles were performed following White et al (1990). The PCR product was purified using a NucleoSpin ${ }^{\circledR}$ Plant DNA purification kit (MACHEREY-NAGEL, Catalogue No. 740 570.50 ), then sequenced automatically by the BIOTEC Service Unit (BSU) laboratory using primers NS1, NS3, NS5 and NS6 (White et al 1990).

Phylogenetic analysis.-Sequences of Ph. brunneispora (Accession numbers: AY580160, AY581944) were analyzed with other sequences obtained from the GenBank database (TABLE I). Morchella esculenta and Helvella terrestris served as outgroups. Sequences were aligned in Clustal W 1.6 program (Thompson et al 1994) and refined visually in Bioedit 
TABLE II. Results of Kishino-Hasegawa maximum likelihood tests on alternative topologies

\begin{tabular}{lcccccccc}
\hline \hline \multicolumn{1}{c}{ Analysis } & $\begin{array}{c}\text { Tree } \\
\text { No. of } \\
\text { trees }\end{array}$ & $\begin{array}{c}\text { Consist- } \\
\text { ency } \\
\text { length }\end{array}$ & $\begin{array}{c}\text { indices } \\
\text { (steps) }\end{array}$ & $\begin{array}{c}\text { Retention } \\
\text { indices } \\
(\mathrm{RI})\end{array}$ & $\begin{array}{c}\text { Rescaled } \\
\text { indices } \\
(\mathrm{RC})\end{array}$ & $\begin{array}{c}-\ln \\
\text { likelihood }\end{array}$ & $\begin{array}{c}\text { Difference } \\
- \text { ln L }\end{array}$ & $P$-value \\
\hline Unweighted parsimony & 2 & 869 & 0.666 & 0.730 & 0.485 & 7430.47546 & 2.00008 & $0.000^{*}$ \\
Weighted parsimony-ti:tv & 1 & 1014.2 & 0.671 & 0.736 & 0.496 & 7429.15521 & 0.67983 & $0.000^{*}$ \\
Maximum likelihood & 1 & - & - & - & - & 7428.47538 & (best) \\
\hline
\end{tabular}

* A significant difference at $P<0.05$.

version 5.0.6 (Hall 2001) and Se-Al v1.Oa1 (Rambaut 1996). The alignment was entered into PAUP* 4.0b10 (Swofford 2002) and MacClade 3.08 (Maddison and Maddison 2001). Phylogenetic trees were generated using unweighted parsimony, weighted parsimony and maximum likelihood criteria on 32 taxa. For the unweighted maximum parsimony analysis, we used a heuristic search with a stepwise starting tree, a random stepwise addition of 100 replicates and treebisection-reconnection branch-swapping algorithm, with gaps treated as missing data. Weighted parsimony analysis was performed using a stepwise matrix to weight nucleotide transformations based on the transition : transversion (ti:tv) ratio, estimated from the dataset using maximum likelihood score in PAUP* (Swofford 2002). Maximum likelihood parameters: ti:tv ratio, proportion of invariable sites, gamma distribution shape parameter and base frequency, also were estimated from the dataset using maximum likelihood score in PAUP*. For the maximum likelihood heuristic searches, we used these settings: stepwise addition of sequence, as-is stepwise addition sequence and TBR branch-swapping algorithm. Tree topologies from unweighted parsimony, weighted parsimony and maximum likelihood analyses were tested with the Kishino-Hasegawa (K-H) maximum likelihood test (Kishino and Hasegawa 1989) to find the most likely tree for the dataset. Bootstrap analysis (Felsenstein 1985) based on unweighted parsimony was performed with full heuristic searches on 1000 replicates, stepwise addition of sequence, 10 replicates of random addition of taxa, treebisection-reconnection branch swapping algorithm. Alignments were deposited in TreeBase: accession no. 51059, matrix accession number $=$ M1806.

\section{RESULTS}

Phylogenetic analyses.-Maximum parsimony analysis of unweighted characters yielded two most parsimonious trees. Of the 1832 characters, 180 were variable $(9.82 \%)$ and 279 parsimony informative (15.2\%). The two trees differed by the position of taxa within the Hypocreales. The K-H test was applied to these trees, which resulted in the best tree for unweighted characters. The weighted parsimony analysis, with the assignment of weight 1.4 to transversion and 1 to transition based on the estimation of ti:tv ratio (ti:tv ratio $=1: 1.47441)$, resulted in one tree with the same topology as the best tree of unweighted parsimony analysis. The result of the K-H test for all trees generated from unweighted, weighted parsimony and maximum likelihood analysis, and the tree generated by the latter method gave the best phylogenetic hypothesis for the dataset (TABLE II). The trees produced by all analyses were significantly different from the most likely tree $(P<0.05)$. However, the tree topology was the same. The maximum likelihood tree (FIG. 17) has given the $-\ln$ likelihood score of 7428.47538. The two strains of Ph. brunneispora sequenced are monophyletic and supported by $100 \%$ bootstrap value. Phylogenetic analyses grouped taxa into three clades. Xylaria species (Xylariales, subclass Xylariomycetidae) formed a basal clade to the subclass Sordariomycetidae. Clade 2 comprises the orders Halosphaeriales, Microascales, Phyllachorales, Hypocreales and Sordariales with high bootstrap support. Clade 3 comprised the Diaporthales, Ophiostomatales and Sordariales incertae sedis, the latter containing various Pseudohalonectria and Ophioceras species. Phruensis brunneispora is well supported in the Diaporthales and groups with Lollipopaia minuta (FIG. 17) with which it shares some morphological characteristics.

\section{TAXONOMY}

Phruensis Pinruan Ascomata immersa, subglobosa, coriacea, nigra, ostiolata, collo longis cylindrica. Peridium compositum ex 2 cellis laminae. Asci cylindrici vel fusiformes, unitunicati, pedecellati, J-, apparatu subapicale praediti. Ascosporae cylindricae, laevis vel curvae, verricolosae, brunneae, 9-11-septatae. Anamorph similis Phialophora.

Etymology. from the Thai Phru, meaning peat swamp and Latin -ensis meaning "pertaining to."

Ascomata immersed, subglobose, black, coriaceous, ostiolate, with long central cylindrical neck. Peridium composed of 2 layers, outer layer parenchymatous, intensely brown and merging with the host cells, inner layer, cells elongate and hyaline. Paraphyses hyaline, broad, septate and attached at the base of the centrum. Asci cylindrical to fusiform, unitunicate, apedicellate, apically rounded, with a re- 

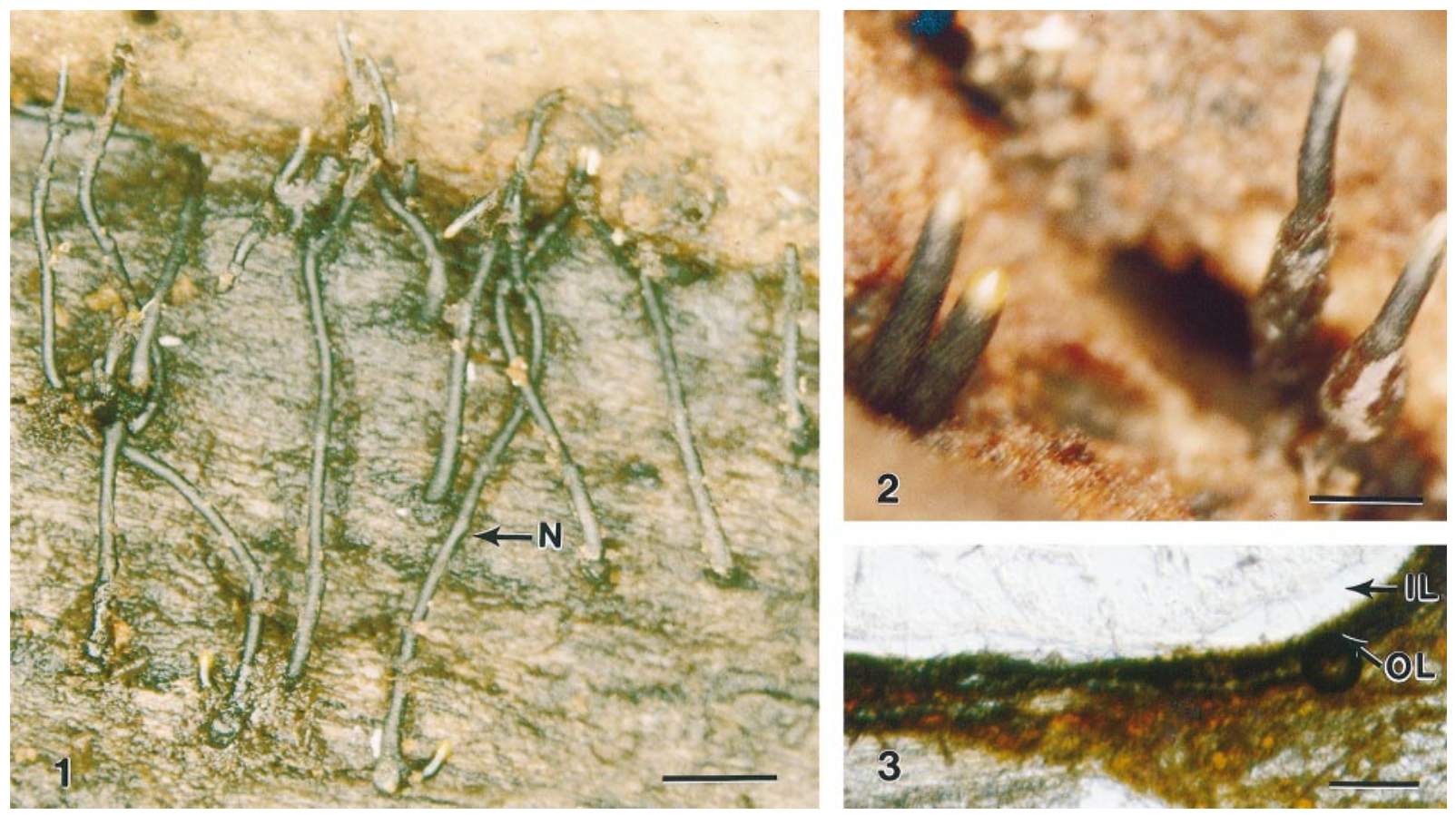

Figs. 1-3. Light micrographs of Phruensis brunneispora (from holotype). 1, 2. Ascomata embedded in the substratum with long necks, tips bright orange. 3. Horizontal section of ascoma with outer perithecial wall (arrow OL) dark brown to black, inner layer (arrow IL) of hyaline elongate cells. Scale bars: $1=10 \mathrm{~mm} ; 2=5 \mathrm{~mm} ; 3=30 \mu \mathrm{m}$.

fractive, J-, subapical ring. Ascospores cylindrical, straight or curved, versicolorous, brown with hyaline or pale brown end cells, transseptate. Anamorph similar to Phialophora.

Typus species. Phruensis brunneispora Pinruan.

Phruensis brunneispora Pinruan, sp. nov. Figs. 1-16

Ascomata 950-980 $\mathrm{\mu m}$ alta, 1.6-1.7 mm diametro, immersa, subglobosa, nigra, coriacea, ostiolata. Collum usque ad $7500 \mu \mathrm{m}$ longum, $500 \mu \mathrm{m}$ diametro, cylindricum, nigrum. Peridium usque ad $250 \mu \mathrm{m}$ crassum, compositum ex 2 cellis laminae. Paraphyses usque ad 12.5-15 $\mu \mathrm{m}$ lata ad basim, Asci 260-275 × 45-50 $\mu \mathrm{m}$, 8-spori, cylindrici vel fusiformes, unitunicati, pedecellati, J-, apparatu subapicale 5$6.3 \mu \mathrm{m}$ alta, 3.75-4.3 $\mu \mathrm{m}$ diametro praediti. Ascosporae $115-120 \times 7.5-8.8 \mu \mathrm{m}, 4$-seriatae vel fasciculatae, cylindricae, laevae vel curvae, brunneae, 9-11-septatae. Anamorph: cf. Phialophora sp.

Holotypus. THAILAND. NARATHIWAT: Sirindhorn Peat Swamp Forest, on dead trunk of Licuala longecalycata, 12 May 2001, U. Pinruan (Wah 113.1) in BIOTEC Bangkok Herbarium (BBH). Culture of type isolate: BCC 11169.

Entymology. From brunneispora, in reference to the brown versicolorous ascospores.

Ascomata 950-980 $\mu \mathrm{m}$ high, 1.6-1.7 $\mathrm{mm}$ diam, deeply immersed, subglobose, black, coriaceous, ostiolate, scattered (FIG. 1). Neck up to $7.5 \mathrm{~mm}$ long, $0.5 \mathrm{~mm}$ diam., central, cylindrical, black, orange at apex (Figs. 1, 2). Peridium up to $250 \mu \mathrm{m}$ thick, comprising 2 layers, outer layer $(40-45 \mu \mathrm{m})$ parenchymatous, intensely brown and merging with the host cells, inner layer, cells elongate and hyaline (25-30 $\mu \mathrm{m}$ ) (Figs. 3, 4). Paraphyses up to 11.2-15 $\mu \mathrm{m}$ wide at the base, hypha-like, tapering distally, not embedded in a gelatinous matrix (FIG. 9). Asci 260-275 $\times$ $45-50 \mu \mathrm{m}(\bar{x}=265 \times 48 \mu \mathrm{m}, \mathrm{n}=25), 8$-spored, cylindro-clavate to fusiform, unitunicate, apedicellate, apically rounded, with a refractive, J-, cuboid subapical ring, 5-6.2 $\mu \mathrm{m}$ high, 3.7-4.2 $\mu \mathrm{m}$ diam, with a faint channel leading to the apex (Figs. 5-8). Ascospores $115-120 \times 7.5-8.7 \mu \mathrm{m}(\bar{x}=116.5 \times 7.8 \mu \mathrm{m}$, $\mathrm{n}=25)$, 4-seriate to fasciculate, cylindrical, straight or curved, versicolored, brown with hyaline to pale brown end cells, 9-11-septate, smooth-walled, with minute ephemeral mucilaginous material at the ends (FIGS. 10-12).

Phialophora-like anamorph: Colonies (BCC 11169) on PDA reaching $2 \mathrm{~cm}$ diam in $7 \mathrm{~d}$ at room temperature (22-24 C), effuse, brown mycelium party immersed, nonstromatic. Conidiophores up to $5 \mu \mathrm{m}$ wide at the base, semimacronematous, mononematous, branched, straight or slightly flexuous, pale brown to brown, smooth. Conidiogenous cells monophialidic, determinate, with small collarettes (Figs. 13, 14). Conidia $11.5-14 \times 1.5 \mu \mathrm{m}(\bar{x}=12 \times 1.5$ $\mu \mathrm{m}, \mathrm{n}=25)$, aggregated in slimy heads, semi-endog- 

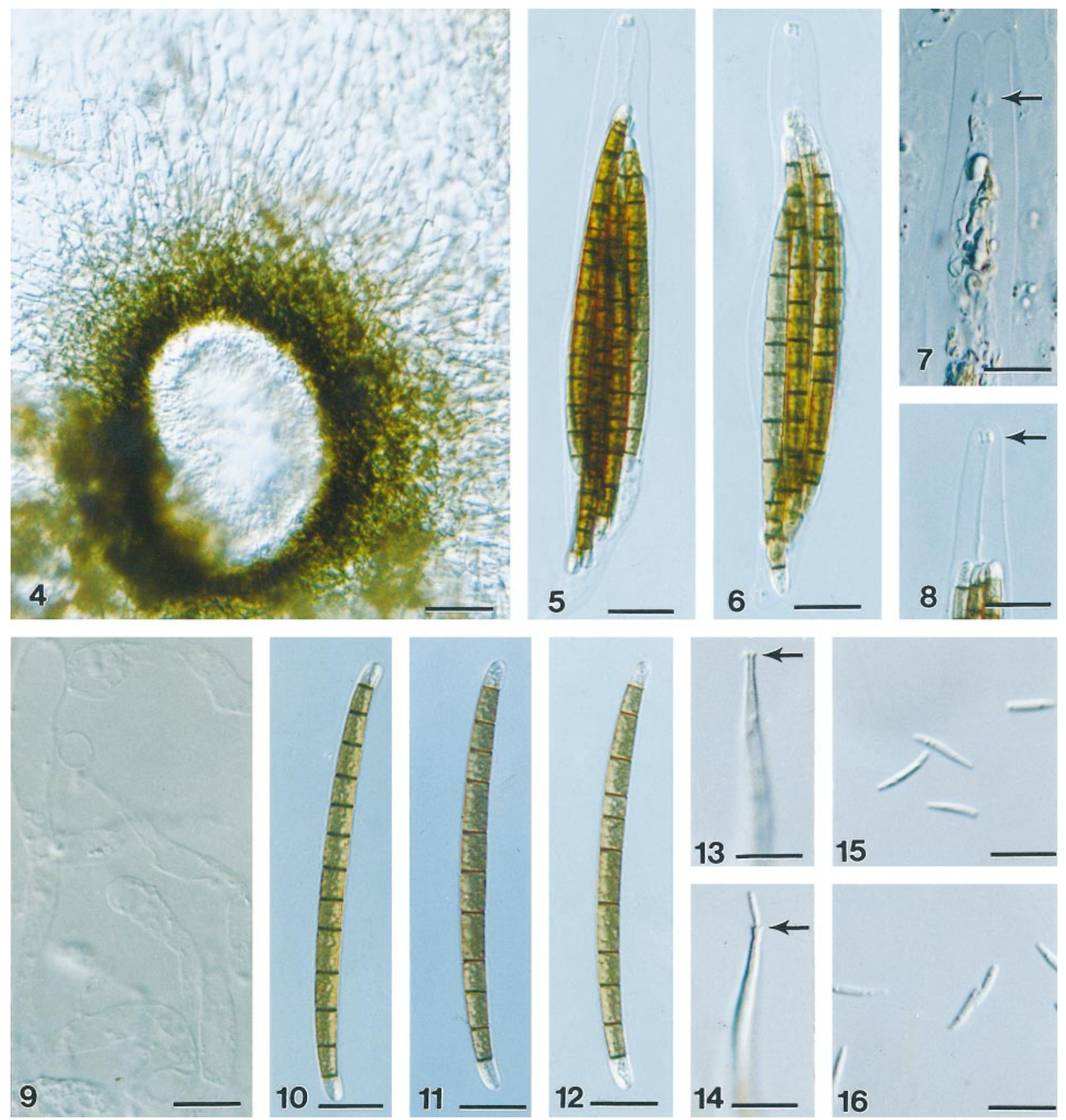

Figs. 4-16. Light micrographs of Phruensis brunneispora (from holotype) and Phialophora-like anamorph. 4. Cross section of neck with fine paraphyses. 5, 6. Asci cylindrical-clavate, ascospores 4-seriate. 7, 8. Cuboid subapical ring (arrows). 9. Hyphalike paraphyses. 10-12. Ascospores with 12-13-septae, central cells brown, end cells hyaline to pale brown. 13, 14. Conidiophores with small collarettes (arrows). 15, 16. Conidia. Scale bars: $4=40 \mu \mathrm{m} ; 5-12=20 \mu \mathrm{m} ; 13-16=10 \mu \mathrm{m}$.

enous, straight or curved, oblong, colorless, smooth, 0 -septate (Figs. 15, 16). Ascomata not formed in culture.

Other collections: THAILAND. NARATHIWAT: Sirindhorn Peat Swamp Forest, on dead trunk of $\mathrm{Li}$ cuala longecalycata, 2 April 2003, U. Pinruan (Wah 113.2) in BBH. Culture from this collection deposited in BCC 14138.

\section{DISCUSSION}

Phylogenetic analyses showed that Phruensis brunneispora belongs in the order Diaporthales. This is supported by various characters such as saprobic on decaying plant material, bilayered ascomata, long and periphysate necks, paraphysate, and unitunicate asci with a refractive, apical J-ring (Barr 1991). Ph. 

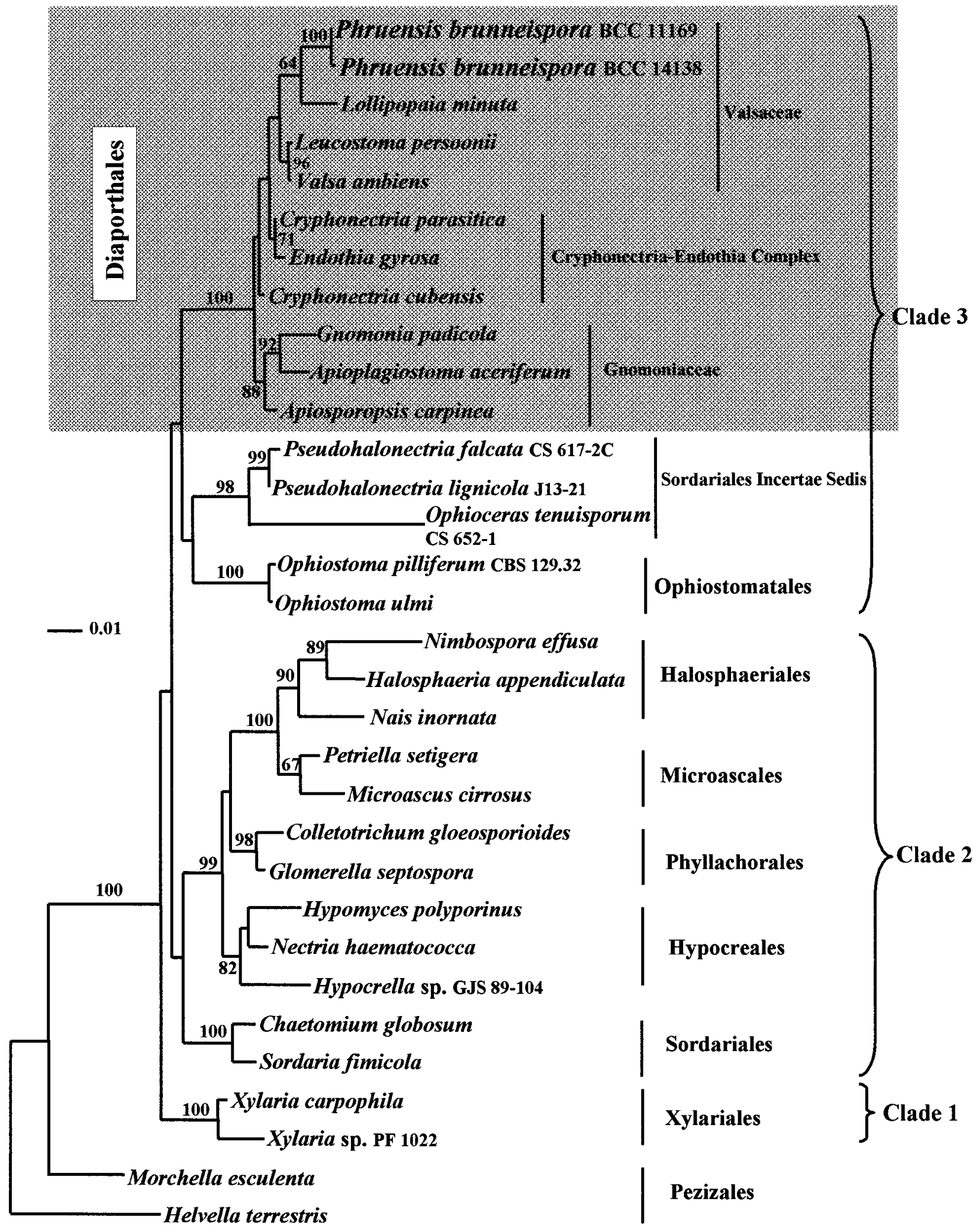

Hypocreales

Pezizales

FIG. 17. A single most likely tree inferred from maximum likelihood analysis ( - ln likelihood score $=7428.47538)$, from partial $18 \mathrm{~S}$ rDNA sequences. Bootstrap values higher than $50 \%$ from maximum parsimony analysis are given on the branches. Scale bar indicates one base substitution per 100 nucleotides. 
brunneispora differs from other members of the Diaporthales in a number of respects: ascomata are not formed in a stroma, although they may be grouped together in the substratum; paraphyses are wide, hypha-like and persistent; and ascospores are falcate with numerous septa. Other genera in the Diaporthales also may have hyaline, falcate ascospores (e.g., Linospora, Sillia).

Phruensis brunneispora most closely resembles Lollipopaia minuta, which also differs morphologically from other taxa of the Diaporthales (Inderbitzin and Berbee 2001). Phruensis brunneispora differs morphologically from L. minuta in that its ascomata are not stromatic, the peridial walls comprise two tissues types and asci have a cuboid subapical, J- ring. In addition, the ascospores of Ph. brunneispora are wider, longer, versicolorous with obvious septa and have hyaline to pale brown end cells. In contrast, Lollipopaia has a weakly developed stroma, asci with a noncuboid apical ring and hyaline ascospores with indistinct septa. Inderbitzin and Berbee (2001) did not refer L. minuta to a family, merely commenting that it could be placed in the Gnomoniaceae sensu Barr (1990) or Valsaceae sensu Hawksworth et al (1995). Similarly, our data do not allow assignment of Phruensis and Lollipopia to a family within the Diaporthales.

Phruensis brunneispora is similar in appearance to species of Ophioceras and Pseudohalonectria (Minoura and Muroi 1978, Shearer 1989, Chen et al 1995, 1999) but differs in having versicolored ascospores. In addition, the ascal rings in Ophioceras and Pseudohalonectria differ in being thimble-shaped and apical rather than cuboid and subapical. Because of their morphological similarity, we included three species of Ophioceras and two species of Pseudohalonectria in our phylogenetic analyses. The analyses supported the morphological data that, although $P h$. brunneispora and the genera Ophioceras and Pseudohalonectria are similar, they are distinct. Phruensis clustered with $100 \%$ bootstrap support (FIG. 17) within the Diaporthales, while Ophioceras and Pseudohalonectria clustered in the Sordariales incertae sedis. This confirms the observations of Inderbitzin and Berbee (2001) that Lollipopaia and Ophioceras/Pseudohalonectria species have little in common and indicates that the latter genera are better placed in the Magnaporthaceae, Sordariales incertae sedis. Chen et al (1999) sequenced a greater number of Ophioceras and Pseudohalonectria species and showed they grouped with Gaeumannomyces, whereas Shearer et al (1999) drew attention to the morphological similarity of these genera with those of the Magnaporthaceae.

\section{ACKNOWLEDGMENTS}

This project is supported by research grant BRT R_145008 and BRTR_245002. We are grateful to Graduate School,
Chiang Mai University, Saisamorn Lumyong, Ruud Valyasevi and Morakot Tanticharoen for continued support, to Ittichai Chatmala and Aom Pinnoi for field assistance and to Manetr Boonyanant and his staff for research facilities at the Sirindhorn Field and Nature Study Center, Narathiwat.

\section{LITERATURE CITED}

Abdel-Wahab MA, Pang KL, El-Sharouny HM, Jones EBG. 2001. Halosarpheia unicellularis sp. nov. (Halosphaeriales, Ascomycota) based on morphological and molecular evidence. Mycoscience 42:255-260.

Barr ME. 1990. Prodromus to nonlichenized, pyrenomycetous members of class Hymenoascomycetes. Mycotaxon 39:43-184.

1991. Revisions and additions to the Diaporthales. Mycotaxon 41:287-305.

Cai L, Tsiu CKM, Zhang K, Hyde KD. 2002. Aquatic fungi from Lake Fuxian, Yunnan, China, Fung Divers 9:5770.

Chen W, Shearer CA, Crane JL. 1999. Phylogeny of Ophioceras spp. based on morphological and molecular data. Mycologia 91:84-94.

$\longrightarrow$, Klopp J. 1995. Phylogenetic ordinal placement based on rDNA sequences of freshwater genera Ophioceras and Pseudohalonectria. Exper Mycol 19:191201.

Choi YW, Hyde KD, Ho WH. 1999. Single spore isolation of fungi. Fung Divers 3:29-38.

Felsenstein J. 1985. Confidence limits on phylogenies: an approach using the bootstrap. Evolution 39:783-791.

Hall T. 2001. Bioedit version 5.0.6., Department of Microbiology, North Carolina State University.

Hawksworth DL, Kirk PM, Sutton BC, Pegler DN. 1995. Ainsworth and Bisby's dictionary of the fungi. 8th ed. Wallingford, UK: International Mycological Institute CAB International. $616 \mathrm{p}$.

Hyde KD, Taylor JE, Fröhlich J. 1999. Two new species of Pseudohalonectria from palms. Mycologia 91:520524.

— fusiforma sp. nov. from palm fronds in Brunei and Thailand. Fung Divers 11:119-122.

Inderbitzin K, Berbee ML. 2001. Lollipopaia minuta from Thailand, a new genus and species of the Diaporthales (Ascomycetes, Fungi) based on morphological and molecular data. Can J Bot 79:1099-1106.

Kishino H, Hasegawa M. 1989. Evaluation of the maximum likelihood estimate of the evolutionary tree topologies from DNA sequence data, and the branching order of Hominoidea. J Mol Evol 29:170-179.

McKenzie EHC, Pinnoi A, Wong MKM, Jones EBG, Hyde KD. 2002. Two new hyaline Chalara species and key to species described since 1975. Fung Divers 11:129-139.

Maddison DR, Maddison WP. 2001. MacClade 3.08. Sinauer Associates Inc. Publishers, Sunderland, Massachusetts.

Minoura K, Muroi T. 1978. Some freshwater Ascomycetes from Japan. Trans Mycol Soc Japan 19:129-134. 
Pinruan U, Jones EBG, Hyde KD. 2002. Aquatic fungi from peat swamp palms: Jahnula appendiculata sp. nov. Sydowia 54:242-247.

Rambaut A. 1996. Se-Al. Department of Zoology, University of Oxford. Oxford OX1 4JD UK.

Shearer CA. 1989. Pseudohalonectria (Lasiosphaeriaceae), an antagonistic genus from wood in freshwater. Can J Bot 67:1944-1955.

-, Crane JL, Chen W. 1999. Freshwater Ascomycetes: Ophioceras species. Mycologia 91:145-156.

Swofford DL. 2002. Phylogenetic analysis using parsimony (*and other methods). Version 5. Sinauer Associates Inc. Publishers, Sunderland, Massachusetts.

Thompson JD, Higgins DG, Gibson TJ. 1994. Clustal W: Improving the sensitivity of progressive multiple sequence alignment through weighting, positions-specific gap penalties and weight matrix choice. Nucleic Acids Research 22:4673-4680.

White TJ, Bruns T, Lee S, Taylor J. 1990. Amplification and direct sequencing of fungal ribosomal RNA genes for phylogenetics. In: Innis MA, Gelfand DH, Sninsky JS, White TJ, eds. PCR Protocol: a guide to methods and applications. San Diego: Academic Press. p 315-322. 